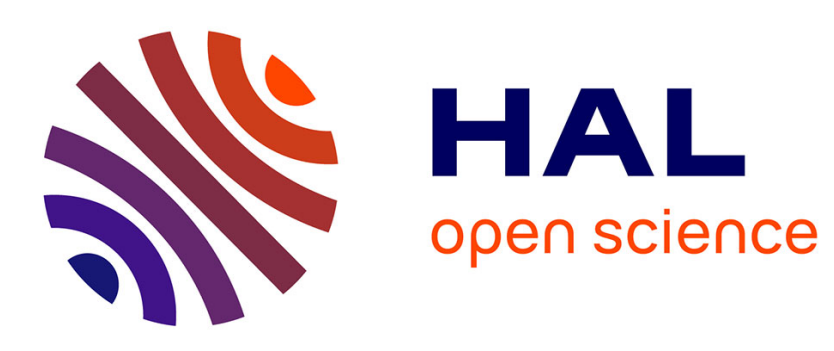

\title{
Solubilization and purification of the lutropin (LH) receptor from porcine testes
}

Bahija Jallal, R. Salesse, J.-M. Bidart, Nadine Martinat, Nicole Genty, Josselin Garnier, Denise Grebert

\section{- To cite this version:}

Bahija Jallal, R. Salesse, J.-M. Bidart, Nadine Martinat, Nicole Genty, et al.. Solubilization and purification of the lutropin (LH) receptor from porcine testes. Reproduction Nutrition Développement, 1988, 28 (4B), pp.1177-1192. hal-00898907

\section{HAL Id: hal-00898907 https://hal.science/hal-00898907}

Submitted on 1 Jan 1988

HAL is a multi-disciplinary open access archive for the deposit and dissemination of scientific research documents, whether they are published or not. The documents may come from teaching and research institutions in France or abroad, or from public or private research centers.
L'archive ouverte pluridisciplinaire HAL, est destinée au dépôt et à la diffusion de documents scientifiques de niveau recherche, publiés ou non, émanant des établissements d'enseignement et de recherche français ou étrangers, des laboratoires publics ou privés. 
Reprod. Nutr. Dévelop., 1988, 28 (4 B), 1177-1192

\title{
Solubilization and purification of the lutropin (LH) receptor from porcine testes
}

\author{
Bahija JALLAL, R. SALESSE, J.-M. BIDART $\left({ }^{*}\right)$, Nadine MARTINAT $\left({ }^{*}\right)$, \\ Nicole GENTY, J. GARNIER
}

with the technical assistance of Denise GREBERT.

Laboratoire de Biochimie physique, I.N.R.A., Université de Paris-Sud Bât. 433, 91405 Orsay Cedex, France.

(*) Département de Biologie clinique, Institut Gustave Roussy, 94805 Villejuif Cedex, France.

(**) Unité Hormones et Gamétogenèse, Station de Physiologie de la Reproduction, I.N.R.A., 37380 Nouzilly, France.

Summary. The LH receptor was solubilized from porcine testis homogenates by different detergents. Non-ionic detergents appeared to be the best ones regarding solubilization yield and recovery of active receptor after elution from hCG affinity gels. However, the final yield was not greater than 1-2\% of the starting receptor activity. We also investigated the effect of added phospholipids ( $75 \%$ phosphatidylcholine $+25 \%$ phosphatidylethanolamine) on the yield of the overall purification process. It was shown that the best $\rho$ value [i.e. the ratio of (detergent concentration - critical micellar concentration) to phospholipids] upon solubilization was $\simeq 1$ for a non-ionic detergent such as Nonidet P-40, while a higher $\rho$ value was better upon elution.

The stability of the solubilized receptor versus $\mathrm{pH}$ and SDS has been studied. The receptor exhibited two $\mathrm{pK}_{\mathrm{a}}$ 's of denaturation $\simeq 3.8$ and 11.1 , while the $\left[{ }^{125} \mathrm{I}\right] \mathrm{hCG}$ receptor complex dissociated with a $\mathrm{pK}_{\mathrm{a}} \simeq 3.8$ and 10.3. SDS concentrations as low as $0.05 \%$ denatured rapidly and apparently, irreversibly, the solubilized LH receptor.

The stability of different affinity gels was checked and it was found that the best yield for receptor elution $(\simeq 10 \%)$ was obtained with an immunoaffinity anti-hCG support. The obtention of two monoclonal antibodies is mentioned, as well as their competition with the binding of $\left[{ }^{125} \mathrm{I}\right] \mathrm{pLH}$ to testis homogenates.

\section{Introduction.}

Several attempts have been made to purify the high affinity receptor for lutropin (LH) since the early work of Dufau et al. [1973]. In these studies, Triton $\mathrm{X}-100$ was used to solubilize the receptor from various gonadal tissues [see review by Roche and Ryan, 1985]. Bruch et al. [1986] and Roche and Ryan [1985] reported the use of other non-ionic detergents, respectively Emulphogen BC 720 and Lubrol PX. The solubilized receptor was then purified by the use of an affinity gel: the gel matrix consisted of $\mathrm{CNBr}$-activated Sepharose or Affigel-10 support on which human choriogonadotropin (hCG) was covalently 
bound by the $\varepsilon$-amino groups of its lysines. Potentially, anti-hCG antibodies [Kim et al., 1987] or even anti-receptor antibodies [Metsikkö and Rajaniemi, 1984] could also be used for immunoprecipitation and even purification [Metsikkö and Rajaniemi, 1980] of the $\mathrm{LH}$ receptor. The receptor was usually eluted from the gel with an acidic buffer ( $\mathrm{pH} 3-4.5)$.

This affinity purification step was reported to yield a highly purified, even homogeneous, receptor [Wimalasena et al., 1985 ; Kusuda and Dufau, 1986]. However, a few authors added additional steps to their purification procedure. Immobilized lectins (wheat germ agglutinin-Sepharose (WGA-Sepharose) [Kusuda and Dufau, 1986 ; Bruch et al., 1986] and Con-A Sepharose [Wimalasena et al., 1985]) were reported to give incomplete binding (about $50 \%$ ) of the receptor with a low purification factor [Bruch et al., 1986], whereas Keinänen et al. [1987b] reported up to $75 \%$ binding of the purified receptor to WGASepharose. Bruch et al. [1986] used differential immunoaffinity to get rid of the major contaminating proteins before their hCG-affinity step.

In our current work on the purification of the $\mathrm{LH}$ receptor, we measured its amount in various gonadal tissues. We also established criteria for the choice of the proper detergent; these were high solubilization and high stability of the receptor in its purified form. We compared the capacity and stability of various affinity supports with hCG linked either by its $\varepsilon$-amino groups or by its sugar moiety. We also determined the physico-chemical properties of the solubilized receptor: molecular weight, affinity [Jallal et al., 1986], $\mathrm{pH}$ stability of the receptor and of the hCG-receptor complex, and denaturation by sodium dodecyl sulfate (SDS), since solubilization and revelation by ligand blotting on nitrocellulose paper from SDS-polyacrylamide electrophoresis gels has been described by Keinänen et al. [1987a].

\section{Material and methods.}

1) Biological products. - Gonads were collected upon castration or slaughtering.

Purified hCG (batch CR121) was a gift of NIH (Bethesda, U.S.A.) and purified porcine LH ( $\mathrm{pLH}$ ) was a gift of Dr Y. Combarnous (Nouzilly, France). Using lodogen bought from Pierce as a caralyzer, the hormones were labeled with ${ }^{125} \mathrm{I}$ to a final activity of 500-1 $000 \mathrm{Ci} / \mathrm{mmole}$ (Genty et al., 1987). Commercial preparations of hCG (Pregnyl) were purchased from Organon. Anti-hCG monoclonal antibodies were prepared in the "Département de Biologie clinique, Institut Gustave Roussy » according to previously described protocols [Bidart et al., 1985]. One monoclonal antibody (HT 13) recognized free hCG, but not hCG-receptor complexes, whereas the other one $\left(D_{1} E_{8}\right)$ recognized either free or receptor-bound hCG [Bidart et al., 1985].

2) Other products. - Affigel-10 was purchased from Bio-Rad, CNBr-activated Sepharose and Agarose adipic acid hydrazide (Agarose gel) from Pharmacia. Immobilized Con-A and wheat-germ agglutinin (WGA) were obtained from IBF 
or Pharmacia. Ultrogel-avidin was from IBF. Biotinyl-hydrazide was purchased from IBF or Sigma. Protease inhibitors came from Serva (phenyl methyl sulfonyl fluoride, PMSF and $\mathrm{N}$-ethyl maleimide, NEM), Boehringer (soybean trypsin inhibitor STI). Detergents were from Packard (Triton X-100), LKB (Nonidet P40), Sigma (Lubrol PX, sodium deoxycholate, saponin), Merck (sodium cholate), Prolabo (SDS), Calbiochem (CHAPS, Zwittergents 3-14 and 3-16). The general properties of the detergents used are summed up in table 1. Crude phosphatidyl choline (PC, from egg yolk) and phosphatidyl ethanolamine (PE, from bovine brain) preparations were purchased from Serva. Other products were reagent grade.

3) Buffers. - The basic buffer (buffer A) contained $10 \mathrm{mM}$ Tris- $\mathrm{HCl}, \mathrm{pH} 7.4$, $100 \mathrm{mM} \mathrm{NaCl}, 3 \mathrm{mM} \mathrm{KCl}, 0.9 \mathrm{mM} \mathrm{CaCl}_{2}, 0.5 \mathrm{mM} \mathrm{MgCl}_{2}, 20 \%$ glycerol. Protease inhibitors: $1 \mathrm{mM}$ NEM, $1 \mathrm{mM}$ PMSF, $30 \mu \mathrm{g} / \mathrm{ml}$ of STI were added to buffer A

TABLE 1

Properties of the detergents used in this study.

\begin{tabular}{|c|c|c|c|c|}
\hline $\begin{array}{c}\text { Detergent } \\
\text { Abbreviation }\end{array}$ & $\begin{array}{l}\text { Molecular } \\
\text { weight }\end{array}$ & $\begin{array}{c}\mathrm{CMC}^{*} \\
(\mathrm{mM} \text { and \%) }\end{array}$ & $\begin{array}{l}\text { Aggregation } \\
\text { number }\end{array}$ & $\begin{array}{c}\text { Micelle } \\
\text { mol. weight }\end{array}$ \\
\hline $\begin{array}{l}\text { Triton } X-100 \\
(T X-100)\end{array}$ & 625 & $\begin{array}{l}0.24 \mathrm{mM} \\
0.015 \%\end{array}$ & 140 & 90000 \\
\hline $\begin{array}{l}\text { Nonidet P-40 } \\
(\text { NP-40) }\end{array}$ & 603 & $\begin{array}{l}0.29 \mathrm{mM} \\
0.017 \%\end{array}$ & 一 & - \\
\hline Lubrol PX & 607 & $\begin{array}{l}0.1 \mathrm{mM} \\
0.006 \%\end{array}$ & $100-150$ & $60-90000$ \\
\hline $\begin{array}{l}\text { Na deoxycholate } \\
\text { (DOC) }\end{array}$ & 415 & $\begin{array}{l}5 \mathrm{mM} \\
0.2\end{array}$ & $4-10$ & $1700-4200$ \\
\hline $\begin{array}{l}\text { Na cholate } \\
\text { (cholate) }\end{array}$ & 431 & $\begin{array}{l}1.4 \mathrm{mM} \\
0.6 \%\end{array}$ & $2-4$ & $900-1800$ \\
\hline Saponin & - & - & - & - \\
\hline CHAPS $^{\dagger}$ & 615 & $\begin{array}{l}8 \mathrm{mM} \\
0.49 \%\end{array}$ & 10 & 6150 \\
\hline $\begin{array}{c}\text { Zwittergent }{ }^{2} \\
\text { 3-14 (Zw 3-14) }\end{array}$ & 364 & $\begin{array}{l}0.33 \mathrm{mM} \\
0.012 \%\end{array}$ & - & - \\
\hline $\begin{array}{c}\text { Zwittergent }{ }^{3} \\
\text { 3-16 (Zw 3-16) }\end{array}$ & 392 & $\begin{array}{r}0.031 \mathrm{mM} \\
0.0012 \%\end{array}$ & 一 & - \\
\hline $\begin{array}{l}\text { Sodium dodecyl } \\
\text { sulfate (SDS) }\end{array}$ & 288 & $\begin{array}{l}8.2 \mathrm{mM} \\
0.23 \%\end{array}$ & 62 & 18000 \\
\hline
\end{tabular}

* : critical micellar concentration.

3-(3-chlolamidopropyl) dimethylammonio-1-propanesulfonate.

: $\mathrm{N}$-tetradecyl-N,N-dimethyl-3-ammonio-1-propanesulfonate.

${ }^{3}: \mathrm{N}$-hexadecyl-N,N-dimethyl-3-ammonio-1-propanesulfonate. 
upon tissue homogeneization (buffer B). Detergents to the desired amount were added to buffer $B$ for tissue solubilization. Buffer $C$ was made with $0.1 \mathrm{M}$ phosphate, $\mathrm{pH} 7.4$, and $0.1 \mathrm{M} \mathrm{NaCl}$ for affinity gel washing. For affinity gel elution, the $\mathrm{pH}$ of buffer $\mathrm{A}$ was adjusted to low $\mathrm{pH}$ with $\mathrm{HCl}$ or to high $\mathrm{pH}$ with $\mathrm{NaOH}$.

4) Preparation of the affinity columns. - The preparation of hCG-adipic acid hydrazide agarose has been described previously, as well as the preparation of biotinyl-hCG for Ultrogel-avidin affinity [Jallal et al., 1986]. hCG-Affigel-10 was prepared according to Metsikkö and Rajaniemi [1982]. hCG was covalently linked to these gels in a proportion of $1 \mathrm{mg}$ per $\mathrm{ml}$ of gel, with a coupling yield of usually more than $90 \%$ as assessed by the amount of hCG dosed in the flow-through of the coupling reaction. In some instances, the subunits of hCG were covalently linked together with ethyl-diamino propyl carbodiimide [Combarnous and Hennen, 1974] prior to gel coupling in order to improve the stability of the hormone. CNBr-Agarose- or Affigel-coupled antibodies were prepared, according to the recommendations of the gel manufacturers, at a ratio of $5-15 \mathrm{mg}$ per $\mathrm{ml}$ of gel.

5) Solubilization of tissue preparations. - Gonadal tissues were usually kept frozen at $-20^{\circ} \mathrm{C}$ until use. The desired amount of starting material was thawed. Testis envelopes were removed. One part (by weight) of tissue was homogeneized with one part (by volume) of cold buffer B in a Waring blendor. The resulting homogenate was then spun at $48000 \times \mathrm{g}\left(30 \mathrm{~min}, 5^{\circ} \mathrm{C}\right)$ in a Sorvall $\mathrm{RCS}$ preparative centrifuge. The pellet was washed in the same conditions and resuspended in one volume of buffer $\mathrm{B}$. It could then be kept frozen at $-20^{\circ} \mathrm{C}$ or be submitted to solubilization by detergents upon agitation with a magnetic or end-to-end stirrer overnight at $4{ }^{\circ} \mathrm{C}$. The solution was then centrifuged at $100000 \times \mathrm{g}$ for $1 \mathrm{~h}$ at $4{ }^{\circ} \mathrm{C}$ in a Beckman 45 Ti rotor. The supernatant was taken as solubilized receptor. It could be stored frozen at $-20{ }^{\circ} \mathrm{C}$ for months in the presence of non-ionic detergents without noticeable loss of $\left[{ }^{125} /\right]$ hCG binding activity. It is however advisable to use solubilized membrane proteins extemporaneously to preserve their native properties [Klausner et al., 1984]. This has been suggested by Wimalasena et al. [1985] and was confirmed in our study.

This solution was then incubated with the chosen affinity gel upon rotative agitation either overnight at $4{ }^{\circ} \mathrm{C}$ or for $3 \mathrm{~h}$ at room temperature. The gel (one volume) was then recovered by centrifugation in conic tubes ( $5 \mathrm{~min}, 1500 \times \mathrm{g}$, $4{ }^{\circ} \mathrm{C}$ ) and washed three times by centrifugation in the same conditions each time with 10 volumes of buffer $\mathrm{C}$. The gel was then treated by 3 volumes of buffer $A$ adjusted to the desired $\mathrm{pH}$ for 2 to $10 \mathrm{~min}$ at room temperature. The supernatant was again collected by centrifugation and its $\mathrm{pH}$ brought back to neutrality. This elution step was repeated in the same way. The last washing was done twice with 3 volumes of buffer $A$. For gel washing and elution, buffers $C$ and $A$ were supplemented or not with $0.2 \mathrm{mg} / \mathrm{ml}$ of phospholipids (75\% PC and $25 \% \mathrm{PE}$ ).

When anti-hCG immunoaffinity gels were used, the procedure was the same except that the $100000 \times \mathrm{g}$ supernatant was incubated for $3 \mathrm{~h}$ at room temperature or overnight at $4{ }^{\circ} \mathrm{C}$ with a sufficient amount of hCG (supplemented 
or not with $\left[{ }^{125} \mathrm{I}\right] \mathrm{hCG}$ tracer) to saturate all receptors present in the solution. Excess $\mathrm{hCG}$ was removed by incubation for $2 \mathrm{~h}$ at room temperature with the HT 13 immunoaffinity gel, and the resulting flow-through was further incubated with the $D_{1} E_{a}$ immunoaffinity gel for $3 \mathrm{~h}$ at room temperature or overnight at $4{ }^{\circ} \mathrm{C}$. Then the receptor was eluted as described above.

6) Analytical methods.

Receptor dosage: determinations were made in triplicate. Prior to assay, plastic tubes were coated with $100 \mu \mathrm{l}$ of a bovine serum previously checked for absence of gonadotropin-like material. $\left[{ }^{125} \mathrm{I}\right] \mathrm{hCG}$ was used as the tracer (50-100 $000 \mathrm{cpm}$ per tube). Non-specific binding was assessed in the presence of an excess of $5 \mu \mathrm{g} /$ tube of cold hCG (Pregnyl). 100-800- $\mu$ l aliquots of the fraction to be dosed were added to each tube and the incubation was carried out for $2 \mathrm{~h}$ at room temperature or overnight at $4{ }^{\circ} \mathrm{C}$. The reaction was stopped by the addition of cold PEG $600030 \%, \mathrm{NaCl} 0.15 \mathrm{M} \mathrm{pH} 7.4$ (1 volume/1 volume of assay solution) and stirring. After $10 \mathrm{~min}$ at $4{ }^{\circ} \mathrm{C}, 1.2 \mathrm{ml}$ of $10 \mathrm{mM}$ Tris- $\mathrm{HCl}$ buffer, $\mathrm{pH} 7.4$, was added and the tubes were centrifuged $10 \mathrm{~min}$ at $3000 \times \mathrm{g}$ and $4{ }^{\circ} \mathrm{C}$. The supernatant was then aspired off and the tubes counted in a gamma counter.

Protein and phospholipid dosages : proteins were dosed with the bicinchoninic acid reagent kit (Pierce) down to $100 \mu \mathrm{g} / \mathrm{ml}$. For lower concentrations, the Aurodye method (Janssen Product), described by Stoscheck [1987] and Hunter and Hunter [1987], was used. Both methods gave results largely independent of the composition of the medium, and particularly of its detergent content. Phospholipids were dosed after extraction by chloroform-methanol (2:1) [Folch et al., 1957]. The chloroformethanol extract was dried and mineralized by $\mathrm{H}_{2} \mathrm{SO}_{4}$ and inorganic phosphorus was dosed [Chen et al., 1956].

Polyacrylamide ge/ electrophoresis : discontinuous buffer polyacrylamide gel electrophoresis was used [Laemmli, 1970]. Sample solutions were boiled for $5 \mathrm{~min}$ in the denaturing buffer containing $50 \%$ glycerol, $3 \%$ sodium dodecyl sulfate (SDS) and $2 \% \beta$-mercapto ethanol. When non-denatured preparations were needed, samples were incubated at room temperature, $\beta$-mercapto ethanol was omitted and the SDS concentration was decreased to $0.05 \%$. Electrophoreses were run at $20^{\circ} \mathrm{C}$ in $7.5 \%$ or $10 \%$ acrylamide gels. Gels were revealed either with Coomassie blue or silver nitrate [Damerval et al., 1987] or with the Kodavue kit (Eastman). In some instances, a Phastsystem electrophoresis apparatus (Pharmacia) was used with a 8-15\% gradient gel.

\section{Results and discussion.}

\section{1) Sources of biological material.}

Several sources were explored regarding their LH receptor content (tabl. 2). Piglet testes were chosen on this basis, and because large supplies were available upon routine castration in country pigsties. Assuming a molecular weight of $10^{5}$, the $\mathrm{LH}$ receptor represented only about $10^{-5}$ of the proteins present in the starting material, which means that a purification factor of about 100000 was needed to reach purity. 
TABLE 2

$L H$ receptor content of different sources.

\begin{tabular}{lcc}
\hline Source & $\begin{array}{c}\text { Proteins } \\
\mathrm{mg} / \mathrm{g} \text { tissue }\end{array}$ & $\begin{array}{c}\text { Receptor } \\
\text { fmoles/mg proteins }\end{array}$ \\
\hline $\begin{array}{c}\text { Porcine testes } \\
10-20 \text { days }\end{array}$ & 51 & $50-200$ \\
\hline $\begin{array}{l}\text { Porcine testes } \\
3 \text { months }\end{array}$ & 55 & $12-127$ \\
\hline MLTC* & 9 & 230 \\
\hline $\begin{array}{l}\text { Rat testes } \\
30 \text { days }\end{array}$ & 42 & 69 \\
\hline $\begin{array}{l}\text { Sow ovary } \\
210 \text { days }\end{array}$ & 28 & 57 \\
\hline
\end{tabular}

* Murine Leydig tumor cells in culture, isolated by Rebois [1982].

2) Effect of usual detergents on receptor activity and solubilization.

In this study, two effects of the detergents were analyzed: (i) interference with the binding of the $\left[{ }^{125} /\right]$ hCG tracer to the solubilized receptor and (ii) receptor solubilization as a function of detergent concentration. Moreover, as SDS was used in electrophoresis experiments, its effect on the dissociation of the preformed hCG-receptor complex and the renaturation of the receptor after SDS treatment were explored.

Effect of detergents on the binding of $\left[{ }^{125} /\right]$ hCG to the solubilized receptor : for this experiment, testis homogenate aliquots $(14 \mathrm{mg} / \mathrm{ml}$ proteins) were solubilized overnight at $4{ }^{\circ} \mathrm{C}$ in buffer $\mathrm{B}$ solutions, each containing $1 \%$ of one detergent. For every detergent, the resulting $100000 \times \mathrm{g}$ supernatant was aliquoted and diluted to the proper amount of detergent. $400 \mu \mathrm{l}$ aliquots of these dilutions were assayed for their $\left[{ }^{125} \mathrm{I}\right] \mathrm{hCG}$ specific binding activity. The detergents used could be divided into three groups (fig. 1). Group 1 : non-ionic detergents (TX-100, NP-40, Lubrol PX), whose increasing concentrations had little effect on hormone binding (fig. 1, top). Group 2: bile salt-derived detergents - sodium cholate, deoxycholate and saponin-which displayed only a narrow range of concentration in which $\left[{ }^{125} \mathrm{I}\right] \mathrm{hCG}$ binding was maximum (fig. 1, middle). For cholate, only low concentrations allowed significant dosage of the receptor. Group 3 : zwitterionic detergents (Zwittergents 3-14 and 3-16), which mimic the overall structure of phospholipids, displayed two ranges of concentration where $\left[{ }^{125}\right]$ hCG binding could happen (fig. 1, bottom). Zwitterionic CHAPS (fig. 1, bottom), which is structurally related to bile salts, allowed better $\left[{ }^{125} \mathrm{I}\right] \mathrm{hCG}$ binding at concentrations above its $\mathrm{CMC}$.

Solubilization of the $L H$ receptor as a function of detergent concentration : aliquots of testis homogenate $(20 \mathrm{mg} / \mathrm{ml}$ proteins) were solubilized with increasing concentrations of the nine detergents. Then, all the $100000 \times \mathrm{g}$ superna- 


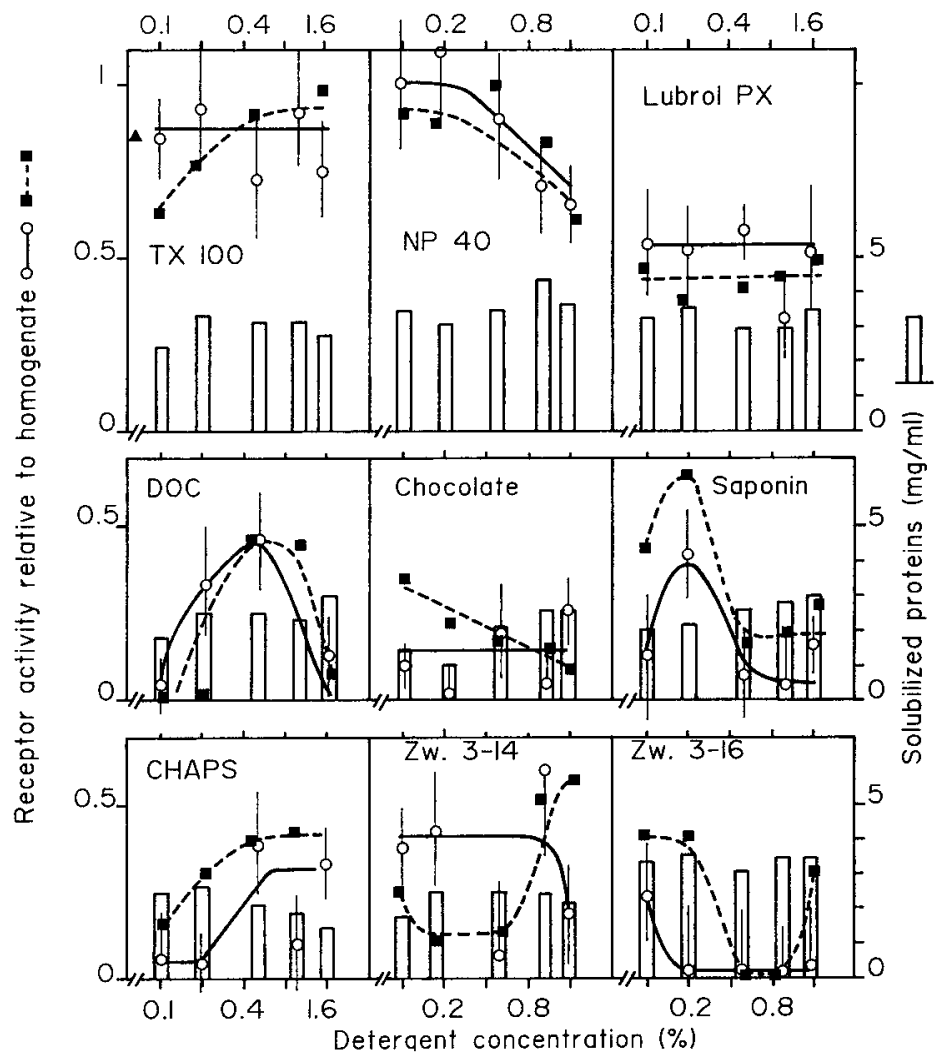

FIG. 1. - Effect of increasing detergents concentration on the binding of $[125 /]$ hCG to solubilized LH

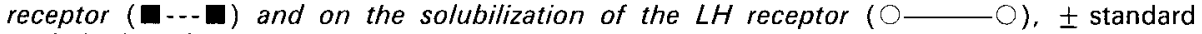
deviation) and proteins (vertical open bars). The detergent concentrations are on a logarithmic scale.

tants were made $(0.5 \%$ in each detergent) and $400 \mu \mathrm{l}$ aliquots of each extract assayed for its $\left[{ }^{125} \mathrm{I}\right] \mathrm{hCG}$ specific binding. Here too, the same three groups were distinguished. The most potent detergents in solubilizing the receptor were the non-ionic ones (fig. 1, top), except Lubrol PX, which yielded only about $50 \%$ solubilized receptor. Bile-salt derivatives displayed a narrow range of useful concentration (fig. 1, middle) and cholate displayed only a low solubilizing potency. Regarding zwitterionic detergents (fig. 1, bottom), CHAPS began to solubilize the receptor above its CMC, which was about $0.49 \%$ [Hjelmeland and Chrambach, 1984. This property of CHAPS has already been utilized by Berthon et al., [1987] to purify the prolactin receptor: they first treated the membrane pellets with low CHAPS concentration to get rid ofcontaminating proteins, then used a higher CHAPS concentration to solubilize the receptor. Zwittergents were already far above their CMC $(0.01 \%$ for Zwittergent $\mathrm{C} 3-14$ and $0.001 \%$ for C3-16) and seemed to be deleterious to the receptor at these relatively high concentrations. 
Triton X-100: Triton X-100 (TX-100) was considered in more detail since it is widely used. As shown in figure 2 (upper part), TX-100 dissolved maximum receptor activity at $0.5 \%$, while maximum protein solubilization was attained at $1 \%$. Using $0.5 \%$ TX -100 instead of $1 \%$ slightly improved the purification factor of this solubilization step. On the other hand, when testis solubilizate was obtained at $1 \%$ TX-100 and then diluted to lower TX-100 concentrations, there was less [ ${ }^{125} \mathrm{l}$ ] hCG specific binding (fig. 2, lower part), very likely because of the aggregation of proteins occurring at lower detergent concentration. This aggregation seemed irreversible since after dilution to $0.1 \% \mathrm{TX}-100$, raising the $\mathrm{TX}-100$ concentration to $1.5 \%$ again did not lead to recovery of receptor activity (not shown).

SDS properties : in experiments like those reported in figure 1, SDS allowed $\left[{ }^{125} /\right]$ hCG binding in a concentration range confined to less than $0.1 \%$. Moreover, it did not solubilize more than $25 \%$ of the active receptor contained in the starting membrane pellet (not shown). The denaturing effect of SDS was investigated in more detail by solubilizing testis homogenates with $1 \% \mathrm{TX}-100$. The resulting $100000 \times \mathrm{g}$ supernatant was diluted to $0.1 \% \mathrm{TX}-100$ and $\left[{ }^{125} \mathrm{I}\right] \mathrm{hCG}$-receptor complexes were preformed in the absence or presence of an excess of $5 \mu \mathrm{g} / \mathrm{ml}$ cold hCG. $400-\mu$ l aliquots were then incubated with $0.1 \%$ SDS at $4{ }^{\circ} \mathrm{C}$ or $20^{\circ} \mathrm{C}$ for $20 \mathrm{~min}$ or $2 \mathrm{~h}$ before PEG 6000 precipitation. The residual $\left[{ }^{125} \mathrm{I}\right] \mathrm{hCG}$ specific binding activity was measured. Figure 3 shows that the denaturing effect of SDS was largely independent of time and temperature in the range tested. It can be seen that increasing SDS concentrations dissociated the complex. Beyond $0.1 \%$, this detergent led to virtually complete dissociation. The reversibility of receptor denaturation by SDS was studied by dialysing out, for 4 days at $4{ }^{\circ} \mathrm{C}$ in buffer $A$ containing $0.15 \mathrm{mg} / \mathrm{ml} \mathrm{PC}$ and $0.05 \mathrm{mg} / \mathrm{ml}$, PE preparations previously solubilized in $0.1 \% \mathrm{SDS}$. This denaturation appeared as irreversible, since dialysis resulted in no recovery of receptor activity (results not shown). This must be taken into account in ligand blotting experiments where no renaturation could happen, and consequently only residual receptor activity could be detected.

\section{3) $\mathrm{pH}$ stability of the receptor and of the hCG-receptor complex.}

The receptor was solubilized by $1 \% \mathrm{TX}-100$ and the $100000 \times \mathrm{g}$ supernatant diluted to $0.1 \% \mathrm{TX}-100$. Aliquots of this solution were incubated for $2 \mathrm{~min}$ or $30 \mathrm{~min}$ at $20^{\circ} \mathrm{C}$ after adjusting their $\mathrm{pH}$ to the desired value with $1 \mathrm{~N} \mathrm{HCl}$ or $1 \mathrm{~N} \mathrm{NaOH}$. The $\mathrm{pH}$ was then brought back to 7.4 and the specific $\left[{ }^{125} \mathrm{I}\right] \mathrm{hCG}$ binding activity assayed on $400 \mu$ l aliquots. It can be seen in figure 4 that the receptor rapidly lost its activity at acid $\mathrm{pH}$ (apparent $\mathrm{pK}\left(\mathrm{pK}_{\mathrm{a}}\right) \simeq 3.8$ ), whereas it retained it in the basic domain, with a sharp collapse beyond $\mathrm{pH} 11\left(\mathrm{pK}_{\mathrm{a}} \simeq 11.1\right)$.

When $\left[{ }^{125} \mathrm{I}\right] \mathrm{hCG}$-receptor complexes (without or with an excess of cold $\mathrm{hCG}$ ) were preformed in the above $0.1 \% \mathrm{TX}-100$ solution, lowering the $\mathrm{pH}$ of the solution resulted in the dissociation of the complexes with the same $\mathrm{pK}$ as for receptor denaturation (fig. 4). In the basic $\mathrm{pH}$ range, dissociation also occurred, but with a $\mathrm{pK}_{\mathrm{a}}$ of 10.3 right before denaturation: this difference in the stability of 

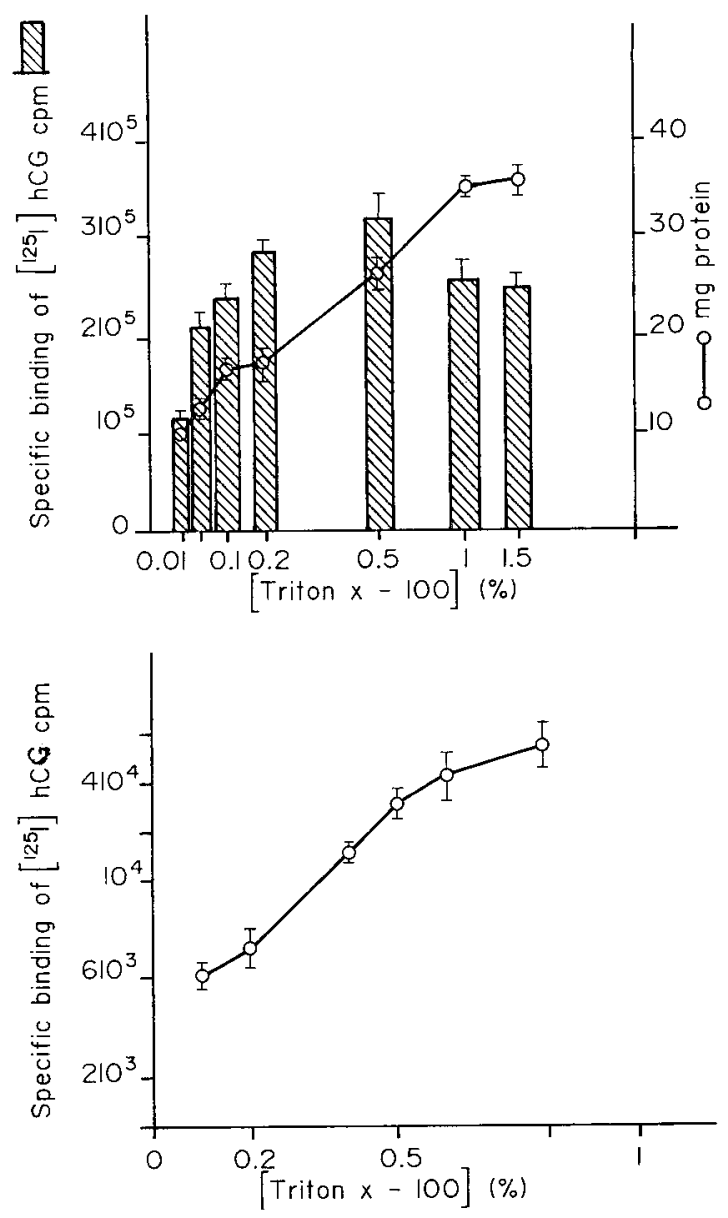

FIG. 2. - Upper part : Effect of TX-100 on the solubilization of the LH receptor (striped bars) and of proteins $(O-O)$. Lower part : Effect of $T X-100$ dilution on the residual receptor activity. The $\mathrm{LH}$ receptor was solubilized overnight at $4{ }^{\circ} \mathrm{C}$ in $1 \% \mathrm{TX}-100$ and the solution diluted with buffer $\mathrm{A}$ to the indicated TX-100 concentrations before dosage. Vertical bars represent two standard deviations.

the receptor and of the hormone-receptor complex at basic $\mathrm{pH}$ was used to advantage in some experiments to eluate the free receptor from the affinity supports.

4) Capacity and stability of hCG affinity supports.

The capacities of the hCG gels were assessed by incubating aliquots of gel with increasing amounts of a $0.1 \% \mathrm{TX}-100$ receptor solution and determining the remaining $\left[{ }^{125} \mathrm{I}\right] \mathrm{hCG}$ binding activity in the flow-through after incubation. $A$ control gel was run each time in parallel with a gel whose active groups had been saturated by amines or aldehydes according to the support used. These control 


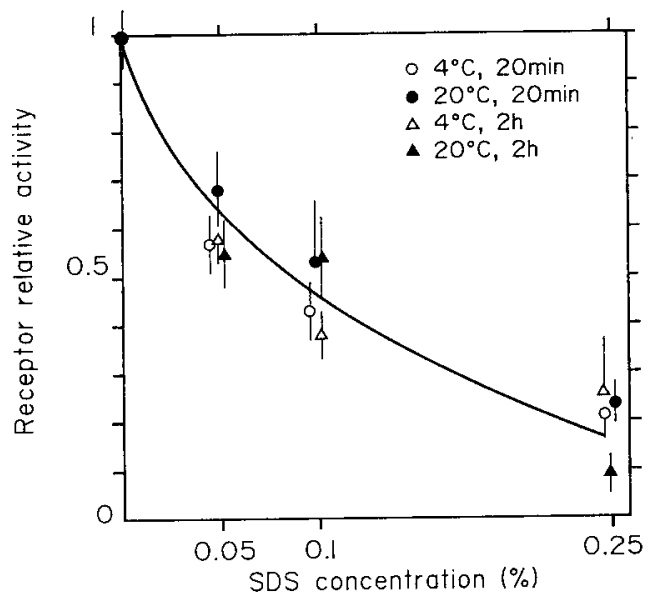

FIG. 3. - Dissociation of the [125/]hCG-receptor complexes by increasing concentration of SDS at two temperatures $\left(4^{\circ} \mathrm{C}\right.$ and $20^{\circ} \mathrm{C}$ ) and two incubation times $(20$ min and $2 \mathrm{~h}$ ). The residual specific $\left[{ }^{125} \mid\right]$ hCG binding is shown \pm standard deviation.

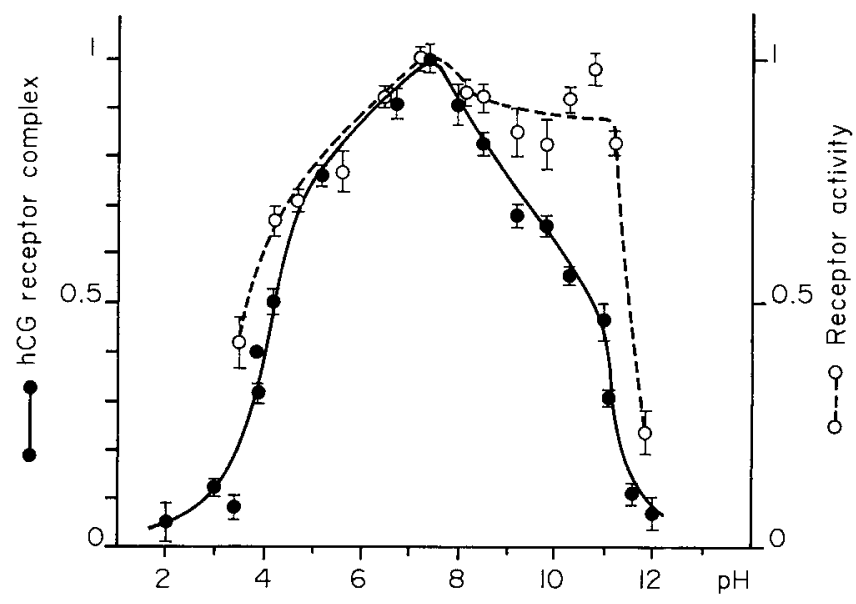

FIG. 4. $-p H$ stability of the $L H$ receptor $(0 \ldots-0)$ and of the $\left[{ }^{125} /\right]$ hCG-receptor complex Vertical bars represent two standard deviations.

gels did not retain any receptor activity, while the hCG-affinity gels displayed a capacity of about 300-400 pmoles of bound receptor per $\mathrm{ml}$ of gel (results not shown), which was far under the expected theoretical capacity based on the amount of hCG coupled to the gel $(1 \mathrm{mg} / \mathrm{ml}$, i.e. $200-300$ nmoles). Gels of immobilized avidin or anti-hCG antibodies were considered as having a similar or slightly higher capacity, though no thorough investigation was made. One 
drawback of the avidin affinity gel was its difficulty of regeneration, since the avidin-biotin association is very strong and only sensitive to extreme $\mathrm{pH}$ 's [Gitlin et al., 1987].

All these gels were stable for months when stored at $4{ }^{\circ} \mathrm{C}$ in a pH 7 buffer with the addition of $0.04 \% \mathrm{NaN}_{3}$. However, they could not be reused after treatment at acidic or basic $\mathrm{pH}$ and washing out. This could be ascribed in part to hCG denaturation, at least at low $\mathrm{pH}$, and perhaps to incomplete release of the receptor during elution (see below).

\section{5) Effect of added phospholipids.}

From studies in model systems, it is known that lipids/detergent/water mixtures display phase transitions according to the concentration of the respective constituents [for review see Helenius and Simons, 1975]. This is very likely why, in our case, cholate, deoxycholate, saponin and the two Zwittergents did not allow dosage of the receptor at certain concentrations (fig. 1). The receptor would become inaccessible to the ligand because of a particular structure of the lipid-detergent phase in water. Moreover, early studies have shown a certain degree of phospholipid dependence in situ of the activity of the LH receptor [Azhar et al., 1976].

We thus added phospholipids at different steps of the purification procedure. As displayed in table 3, phospholipids did not seem to play a crucial role in the solubilization step when NP-40 was used as the detergent, though they themselves had a slight solubilizing power. They even seemed to lower the yield of purification, perhaps because of the pelleting of receptor-containing liposomes during $100000 \times \mathrm{g}$ centrifugation. However, their presence during the extraction seemed to be beneficial to elution (performed in the presence of $0.2 \mathrm{mg} / \mathrm{ml}$ phospholipids), because receptor activity was found only in those eluates where solubilization was made at $\rho$ values of about 1 . This $\rho$ value could be defined as the ratio: (detergent concentration - CMC)/phospholipids concentration, which has been reported as specific to each given protein/detergent/phospholipid system [Helenius and Simons, 1975 ; Klausner et al., 1984].

The detergent/phospholipid effect on the elution step was further investigated by changing the $\rho$ value of the elution solution after solubilization at different detergent concentrations. Table 4 shows that, in solubilization conditions previously delineated as the best ones, raising the $\rho$ value of the elution solution seemed to slightly raise the yield of active receptor recovered upon the elution step. In conclusion, this study shows that, at least for non-ionic detergents (NP 40 in this case), a $\rho$ value of about 1 or more must be used throughout the purification procedure to obtain the most favorable yield in active $\mathrm{LH}$ receptor.

\section{6) Purification with anti-hCG immunoaffinity.}

If the receptor was sensitive to denaturation, one of the means to protect it would be to purify the hCG-receptor complex instead of the receptor alone. Thus the $L H$ receptor was solubilized and bound to $h C G$ as described under « Materials and methods». Doing this, the yield of elution at $\mathrm{pH} 10.8$ from this immunoaffinity gel reached $11 \pm 2 \%$ instead of $1-2 \%$ with the hCG-affinity ones. One 
TABLE 3

Effect of different NP-40/phospholipids (PL) ratios on the solubilization and elution of the $L H$ receptor.

\begin{tabular}{|c|c|c|c|c|c|c|}
\hline \multirow{3}{*}{$\begin{array}{l}\text { Concentration } \\
\text { of } \\
\text { NP- } 40(\%)\end{array}$} & \multicolumn{3}{|c|}{$\begin{array}{c}\text { No PL added } \\
\text { (5 } \mathrm{mg} / \mathrm{ml} \text { endogenous) }\end{array}$} & \multicolumn{3}{|c|}{$\begin{array}{c}5 \mathrm{mg} / \mathrm{ml} \mathrm{PL} \text { added } \\
(5 \mathrm{mg} / \mathrm{ml} \text { endogenous })\end{array}$} \\
\hline & \multirow[b]{2}{*}{$\rho^{*}$} & \multicolumn{2}{|c|}{ percent recovery upon } & \multirow[b]{2}{*}{$\rho^{*}$} & \multicolumn{2}{|c|}{ percent recovery upon } \\
\hline & & $\begin{array}{l}\text { solubili- } \\
\text { zation }\end{array}$ & $\begin{array}{l}\mathrm{pH} 10.8 \\
\text { elution }\end{array}$ & & $\begin{array}{l}\text { solubili- } \\
\text { zation }\end{array}$ & $\begin{array}{l}\mathrm{pH} 10.8 \\
\text { elution }\end{array}$ \\
\hline 0 & 0 & $4 \pm 13$ & & 0 & $31 \pm 15$ & \\
\hline 0.1 & 0.15 & $24 \pm 12$ & 0 & & & \\
\hline 0.2 & 0.34 & $77 \pm 14$ & $0.6 \pm 0.4$ & 0.18 & $45 \pm 13$ & 0 \\
\hline 0.5 & 0.89 & $68 \pm 15$ & $1.3 \pm 0.4$ & 0.46 & $59+9$ & 0 \\
\hline 0.8 & 1.45 & $70 \pm 11$ & $0.2 \pm 0.5$ & 0.75 & $85 \pm 12$ & 0 \\
\hline 1 & 1.82 & $72 \pm 16$ & $\overline{0}$ & 0.95 & $45 \pm 12$ & $1 \pm 0.5$ \\
\hline 1.5 & 2.75 & $53 \pm 21$ & 0 & 1.43 & $52 \pm 13$ & $0.6 \pm 0.4$ \\
\hline 2.5 & 4.6 & $50 \pm 7$ & $0.3 \pm 0.5$ & 2.39 & $18 \pm 8$ & $0.2 \pm 0.4$ \\
\hline
\end{tabular}

$\rho^{*}=$ (detergent concentration - CMC)/phospholipids concentration.

Membrane pellet $(27 \mathrm{mg} / \mathrm{ml}$ proteins, $5 \mathrm{mg} / \mathrm{ml}$ endogenous phospholipids) was solubilized at $4{ }^{\circ} \mathrm{C}$ overnight at the indicated NP-40 concentrations without or with the addition $0 \mathrm{mg} / \mathrm{ml}$ phospholipids $(3.75 \mathrm{mg} / \mathrm{ml} \mathrm{PC}$ and $1.25 \mathrm{mg} / \mathrm{ml} \mathrm{PE})$. The affinity gel used was hCG-agarose. It was washed and eluted with respectively buffer $\mathrm{C}$ and buffer $\mathrm{A}$ at $\mathrm{pH} 10.8$, each containing $0.2 \mathrm{mg} / \mathrm{ml}$ phospholipids. Activities recovered in the $\mathrm{pH} 10.8$ eluate and in the subsequent washing were added in the column « percent recovery upon $\mathrm{pH} 10.8$ elution ». Recovered receptor activities are reported to the receptor activity as dosed in the starting membrane pellet.

TABLE 4

Effect of phospholipid (PL) addition on the $\mathrm{pH} 10.8$ elution of the $L H$ receptor from the hCG-agarose affinity gel.

\begin{tabular}{cc|cccc}
\hline \multicolumn{2}{c|}{ Solubilization } & \multicolumn{5}{|c}{ Elution } \\
\hline $\begin{array}{c}\text { PL added } \\
(\mathrm{mg} / \mathrm{ml})\end{array}$ & $\rho$ & $\begin{array}{c}\text { NP-40 } \\
(\%)\end{array}$ & $\begin{array}{c}\text { PL added } \\
(\mathrm{mg} / \mathrm{ml})\end{array}$ & $\rho$ & $\begin{array}{c}\text { Yield of the } \\
\text { elution step (\%) }\end{array}$ \\
\hline 0 & 0.89 & 0 & 0.2 & 0 & 1 \\
0 & 0.89 & 0.05 & 0.2 & 1.65 & $1.5 \pm 0.7$ \\
0 & 0.89 & 0.5 & 0.2 & 24.1 & $1.6 \pm 0.4$ \\
\hline 0 & 1.42 & 0 & 0 & - & $0.4 \pm 0.2$ \\
0 & 1.42 & 0.2 & 0 & - & 0.4 \\
\hline 1 & 1 & 0 & 0.2 & 0 & $0.4 \pm 0.3$ \\
1 & 1 & 0.2 & 0.2 & 9.15 & $1.1 \pm 0.2$ \\
\hline
\end{tabular}

Membrane pellets at different lipid (and protein) concentrations (the value of $\rho$ is indicated) were solubilized at $4{ }^{\circ} \mathrm{C}$ overnight at $0.5 \%$ NP-40 concentration without or with the addition of $1 \mathrm{mg} / \mathrm{ml}$ phospholipids ( $75 \% \mathrm{PC}$ and $25 \% \mathrm{PE}$ ). The affinity gel used was hCG-agarose. It was washed and eluted with respectively buffer $\mathrm{C}$ and buffer $\mathrm{A}$ at $\mathrm{pH} 10.8$, each containing $0.2 \mathrm{mg} / \mathrm{ml}$ phospholipids. Activities recovered in the $\mathrm{pH} 10.8$ eluate and in the subsequent washing were added in the column " yield of elution step ». Recovered receptor activities are reported to the receptor activity as dosed in the starting membrane pellet. 
interesting point is that when $\left[{ }^{125} \mathrm{I}\right] \mathrm{hCG}$ was complexed to the receptor before the immunoaffinity step, very little or no radioactivity was found in the $\mathrm{pH} 10.8$ eluate, while receptor activity could still be detected. $\left[{ }^{125} /\right.$ ] hCG radioactivity could be eluted only at $\mathrm{pH} 2$. These results signify that $\mathrm{hCG}$ remained on the gel while the receptor was at least partly eluted.

\section{7) Echange of detergent on the affinity column.}

For these experiments, a $100000 \times \mathrm{g} \mathrm{NP} 40$ extract, obtained at $0.5 \%$ detergent $(20 \mathrm{mg} / \mathrm{ml}$ proteins and $\rho=1.2)$, was incubated with the Agarose-hCG affinity gel. Further, the gel was washed batchwise for $1 \mathrm{~h}$ at room temperature with buffer $\mathrm{C}$ containing $0.5 \%$ of each of the other detergents used in this study, except SDS. The receptor was then eluted at $\mathrm{pH} 10.8$ in buffer A containing $0.5 \%$ of the replacement detergent. This technique did not increase the amount of active receptor recovered, since only the non-ionic detergents gave an elution yield of about $1 \%$ (results not shown).

\section{8) Obtention of monoclonal antibodies.}

The receptor was solubilized in $1 \% \mathrm{TX}-100$ and purified by two successive affinity steps on a Agarose-hCG gel with $\mathrm{pH} 3$ elution [Jallal et al., 1986]. This preparation (about 3 pmoles $/ \mathrm{ml}$ receptor, about $40 \mu \mathrm{g} / \mathrm{ml}$ proteins) was used to raise monoclonal antibodies (MAbs). Culture supernatants of hybridomas were screened for inhibition of $\left[{ }^{125} \mathrm{I}\right] \mathrm{hCG}$ or $\left[{ }^{125} \mathrm{I}\right] \mathrm{pLH}$ binding. For this purpose, different dilutions of these supernatants were preincubated overnight at $4{ }^{\circ} \mathrm{C}$ with testicular homogenate. The hormone tracer was then added and its displacement by the MAb compared to the one obtained with a known amount of cold hormone. Two MAbs, namely RG-05 and RG-08, were able to compete in a dose-dependent way with $\left[{ }^{125} \mathrm{I}\right] \mathrm{pLH}$ for binding to porcine testicular homogenate (fig. 5).

\section{Conclusion.}

This set of results points out the difficulty in purifying a membrane receptor which represents about $10^{-5}$ of the proteins present in the starting material. The final yield and purity could appear as very low when compared to previously published results concerning the LH receptor or other membrane receptors. But they are of the same order as the one reported for the prolactin receptor [Katoh et al., 1987]. Nevertheless, the purified product was used successfully to raise MAbs against it, which shows that a sufficient level of purity had been reached.

There are now questions pending concerning potential improvements in the purification of the LH receptor. Some of them pertain to the detergent used, namely : is a good solubilizing detergent still good for further purification steps? In the literature one can find examples where the solubilizing detergent is replaced by another one at a determined step of the purification [see review in Helenius and Simons, 1975 and Levitsky, 1985]. Among purified receptors, it is also known that the choice of detergent is crucial in maintaining activity throughout 


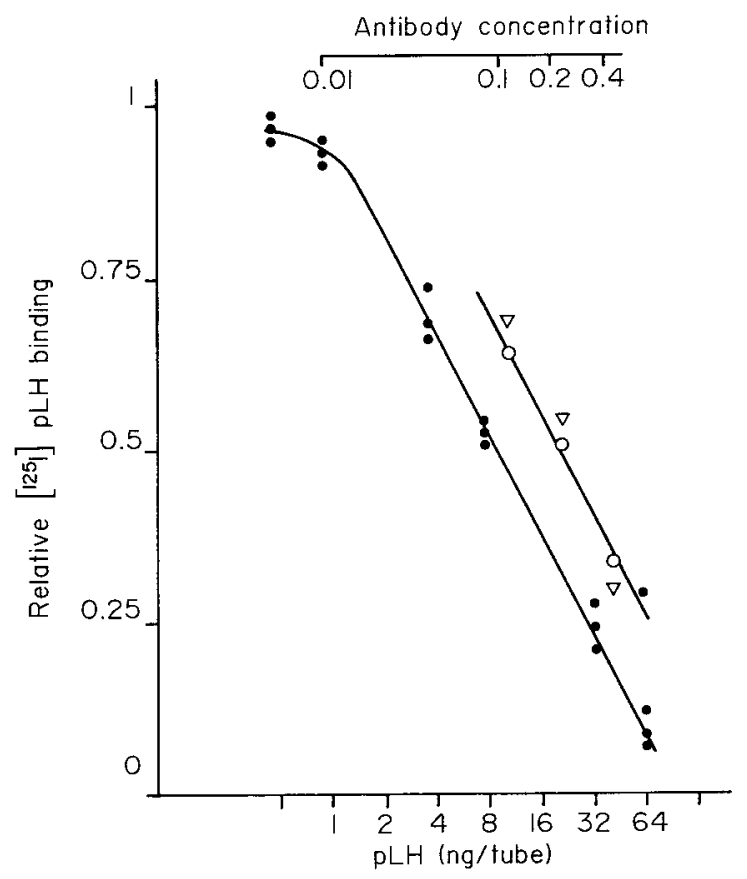

FIG. 5. - Competition of two monoclonal antibodies (RG-15: $\nabla$ ) and (RG-18: 0 ) with the binding of $[25 /] p L H$ to porcine testes homogenate. Supernatants of hybridoma culture were diluted to the indicated concentrations.

the purification procedure [see review by Levitsky, 1985] with a proper $\rho$ value. However, the most promising way of improving the purification method seems to be the immunoaffinity procedure since the hCG-receptor complex seems to be protected, at least partially, from denaturation during the affinity and/or elution step.

Here, we have delineated several conditions in which the LH receptor, extracted with non-ionic detergents, can be handled with minimal loss of activity. We have defined conditions of stability of the receptor regarding its behavior versus $\mathrm{pH}$ or detergents. Moreover, we have found that the hCG-receptor complex dissociated readily at high $\mathrm{pH}$ without denaturation of either the receptor or the hormone, which was used to recover the receptor after its uptake by hCG affinity columns. This set of results will be used to advantage for further characterization of the $\mathrm{LH}$ receptor.

Reçu en octobre 1987 Accepté en avril 1988.

Acknowledgements. - We are grateful to MM. Bonneau (La Minière, I.N.R.A.), Noël (Bel Air, Chambre d'Agriculture d'lle-de-France), Le Bost (Rennes-St-Gilles, I.N.R.A.), Pinault (COOPERL, Lamballe), Dabiel (CADS, Le Mans) and "Institut Technique du Porc" at 
Rennes for their help in providing us with the porcine testes. We thank Dr. R. V. Rebois (NIH, Bethesda, USA) for the gift of the MLTC cell strain. We thank Dr. Y. Combarnous (I.N.R.A., Nouzilly) for the gift of pLH. We are indebted to the Center for Population Control, NIH, for providing us with hCG through the courtesy of Dr. R. Canfield (Columbia University, New York). This work was supported in part by grants from « Institut National de la Recherche Agronomique "(1) "Centre National de la Recherche Scientifique", "Ministère des Relations Extérieures », «Fondation de la Recherche Médicale », " Ministère de la Recherche et de l'Enseignement Supérieur » and "Association pour la Recherche sur le Cancer»".

Résumé. Solubilisation et purification du récepteur de la lutropine ( $L H)$ de testicules de porc.

Le récepteur de LH a été solubilisé par différents détergents à partir d'homogénat de testicules de porcelet. Les meilleurs rendements de solubilisation du récepteur ont été obtenus grâce aux détergents non ioniques. Cependant, le rendement final de purification, après élution d'un gel d'affinité portant l'hCG comme ligant immobilisé ne dépassait pas 1 à $2 \%$ de récepteur actif par rapport à l'homogénat de départ. Nous avons également examiné l'effet de l'addition de phospholipides ( $75 \%$ phosphatidyllcholine $+25 \%$ phosphatidyléthanolamine) dans les tampons au cours de la purification. Nous avons observé que la meilleure valeur de $\rho$ [c'est-à-dire le rapport de (concentration du détergent-concentration micellaire critique) à la concentration en phospholipides] était voisine de 1 pour la solubilisation du récepteur par un détergent non ionique comme le Nonidet $\mathrm{P} 40$, mais qu'une valeur supérieure à 1 était nécessaire lors de l'élution.

Nous avons étudié la stabilité du récepteur en fonction du $\mathrm{pH}$ et de la concentration en SDS. Le récepteur présente deux pKa de dénaturation, l'un à 3,8 , l'autre à 11,1 , tandis que le complexe hCG-récepteur se dissocie avec un pK de 3,8 et un pK de 10,3. Le récepteur solubilisé est dénaturé irréversiblement par le SDS dès $0,05 \%$.

Nous avons testé la stabilité, la capacité et le rendement d'élution de différents gels d'affinité. Le meilleur rendement d'élution en récepteur actif (10\%) a été observé pour un gel portant un anticorps anti-hCG comme ligand. Le récepteur purifié a été utilisé pour obtenir des anticorps monoclonaux, dont deux étaient capables d'entrer en compétition avec la $\left[{ }^{125} \mathrm{I}\right] \mathrm{LH}$ pour la liaison à un homogénat testiculaire.

\section{References}

AZHAR S., HAJRA A. K., MENON K. M. J., 1976. Gonadotropin receptors in plasma membranes of bovine corpus luteum. J. biol. Chem., 251, 7405-7412.

BERTHON P., KATOH M., DUSANTER-FOURT I., KELLY P. A., DJIANE J., 1987. Purification of prolactin receptor from sow mammary gland and polyclonal antibody production. Mol. cell. Endocrinol., 51, $71-81$.

BIDART J.-M., OZTURK M., BELLET D. H., JOLIVET M., GRAS-MASSE H., TROALEN F., BOHUON C. J., WANDS J. R., 1985. Identification of epitopes associated with hCG and the $\beta$ hCG carboxyl terminus by monoclonal antibodies produced against a synthetic peptide. $J$. Immunol., 134, 457-464.

BRUCH R. C., THOTAKURA N. R., BAHL O.P., 1986. The rat ovarian lutropin receptor. Purification, hormone binding properties and subunit composition. J. biol. Chem., 261, 9450-9460.

CHEN P. S., TORIBARA T. Y., WARNER H., 1956. Microdetermination of phosphorus. Anal. Chem., 28, 1756-1758.

(1) ATP «Hormones hypophysaires et fonction de reproduction chez les Vertébrés ». 
COMBARNOUS Y., HENNEN G., 1974. Luteinizing hormone derivatives with covalently-linked subunits. FEBS Lett., 44, 224-228.

DAMERVAL C., LE GUILLOUX M., BLAISONNEAU J., DE VIENNE D., 1987. A simplification of Heukeshoven and Dernick's silver staining of proteins. Electrophoresis, 8, 158-159.

DUFAU M. L., CHARREAU E. H., CATT K. J., 1973. Characteristics of a soluble gonadotropin receptor from the rat testis. J. biol. Chem., 248, 6973-6982.

FOLCH J., LEES M., SLOANE-STANLEY G. H., 1957. A simple method for the isolation and purification of total lipids from animal tissues. J. biol. Chem., 226, 497-509.

GENTY N., SALESSE R., GARNIER J., 1987. Internalization and recycling of lutropin receptors upon stimulation by porcine lutropin and human choriogonadotropin in porcine Leydig cells. Biol. Cel/s, 59, 129-136.

GITLIN G., BAYER E. A., WILCHEK M., 1987. Studies on the biotin-binding site of avidin. Lysines residues involved in the active site. Biochem. J., 242, 923-926.

HELENIUS A., SIMONS K., 1975. Solubilization of membranes by detergents. Biochim. Biophys. Acta, 415, 29-79.

HJELMELAND L. M., CHRAMBACH A., 1984. Solubilization of functional membrane proteins. Meth. Enz., 104, 305-318.

HUNTER J. B., HUNTER S. M., 1987. Quantification of proteins in the low nanogram range by staining with the colloidal gold stain Aurodye. Anal. Biochem., 164, 430-433.

JALLAL B., SALESSE R., GARNIER J., 1986. Un gel d'affinité à haute capacité pour la purification du récepteur testiculaire de la lutropine. C. R. Acad. Sci. Paris, Sér., III, 303, 73-76.

KATOH M., RAGUET S., ZACHWIEJA J., DJIANE J., KELLY P. A., 1987. Hepatic prolactin receptors in the rat : characterization using monoclonal antireceptor antibodies. Endocrinology, 120, 739-749.

KEINÄNEN K., KELLOKUMPU S., RAJANIEMI H. J., 1987a. Visualization of the rat ovarian Iutropin receptor by ligand blotting. Mol. cell. Endocrinol., 49, 33-38.

KEINANEN K. P., KELLOKUMPU S., METSIKKO M. K., RAJANIEMI H. J., 1987b. Purification and partial characterization or rat ovarian lutropin receptor. J. biol. Chem., 262, 7920-7926.

KIM I.-C., ASCOLI M., SEGALOFF D. L., 1987. Immunoprecipitation of the lutropin/hCG receptor from biosynthetically labeled Leydig tumor cells. J. biol. Chem., 262, 470-477.

KLAUSNER R. D., VAN RENSWOUDE J., BLUMENTHAL R., RIVNAY B., 1984 . Reconstitution of membrane receptors. In Molecular and chemical characterization of membrane receptors, Alan R. LISS, New York, 209-239.

KUSUDA S., DUFAU M. L., 1986. Purification and characterization of the rat ovarian receptor for luteinizing hormone. Structural studies of subunit interactions. J. biol. Chem., 261, $16161-16168$.

LAEMMLI U. K., 1970. Cleavage of structural proteins during the assembly of the head of bacteriophage $\mathrm{T}_{4}$. Nature, 227, 680-685.

LEVITSKY A., 1985. Reconstitution of membrane-receptor systems. Biochim. Biophys. Acta, 822, $127-153$

METSIKKÖ M. K., RAJANIEMI H. J., 1980. Purification of luteinizing hormone receptor and its subunit structure. Biochem. Biophys. Res. Commun., 95, 1730-1736.

METSIKKÖ M. K., RAJANIEMI H. J., 1982. The hormone binding unit of luteinizing hormone receptor. Biochem. J., 208, 309-316.

METSIKKÖ M. K., RAJANIEMI H. J., 1984. Immunoprecipitation of the lutropin receptor. Loss of receptor molecules during down-regulation. Biochem. J., 224, 467-471.

REBOIS R. V., 1982. Establishment of gonadotropin-responsive murine Leydig tumor cell line. $J$. Cell Biol., 94, 70-76.

ROCHE P. C., RYAN R. J., 1985. The LH/hCG receptor, 17-56. In ASCOLI M., Luteinizing action and receptor, CRC Press, Boca Raton, Florida.

STOSCHECK C. M., 1987. Protein assay sensitive at nanogram levels. Anal. Biochem., 160, $301-305$

WIMALASENA J., MOORE P., WIEBE J. P., ABEL J. Jr., CHEN T. T., 1985. The porcine LH/hCG receptor : characterization and purification. J. biol. Chem., 260, 10689-10697. 